\title{
Historical changes in sediments of Pyramid Lake, Nevada, USA: consequences of changes in the water balance of a terminal desert lake
}

\author{
Martin E. Lebo, ${ }^{1}$ John E. Reuter ${ }^{1}$ \& Philip A. Meyers ${ }^{2}$ \\ ${ }^{1}$ Division of Environmental Studies, University of California, Davis, CA 95616, USA \\ ${ }^{2}$ Department of Geological Sciences, University of Michigan, Ann Arbor, MI 48109, USA
}

Received 6 January 1994; accepted 30 July 1994

Key words: Great Basin, climatic variations, productivity, organic matter, nitrogen, phosphorus, hardwater lake

\begin{abstract}
Sediment cores from the shallow and deep basins of Pyramid Lake, Nevada, revealed variations in composition with depth reflecting changes in lake level, river inflow, and lake productivity. Recent sediments from the period of historical record indicate: (1) $\mathrm{CaCO}_{3}$ and organic content of sediment in the shallow basin decrease at lower lake level, (2) $\mathrm{CaCO}_{3}$ content of deep basin sediments increases when lake level decreases rapidly, and (3) the inorganic $\mathrm{P}$ content of sediments increases with decreasing lake volume. Variations in sediment composition also indicate several periods for which productivity in Pyramid Lake may have been elevated over the past 1000 years. Our data provide strong evidence for increased productivity during the first half of the 20th Century, although the typical pattern for cultural eutrophication was not observed. The organic content of sediments also suggests periods of increased productivity in the lake prior to the discovery and development of the region by white settlers. Indeed, a broad peak in organic fractions during the 1800's originates as an increase starting around 1600 . However, periods of changing organic content of sediments also correspond to periods when inflow to the lake was probably at extremes (e.g. drought or flood) indicating that fluctuations in river inflow may be an important factor affecting sediment composition in Pyramid Lake.
\end{abstract}

\section{Introduction}

Sediments provide a wealth of information about spatial variability and historical changes in lake ecosystems. Generally, sediments accumulate in lakes at a few $\mathrm{mm} \mathrm{yr}^{-1}$ (Lerman, 1979), with low rates of accumulation typical in large lakes (Kendall, 1969; Eadie et al., 1984; Edgington et al., 1991). Low sedimentation rates in large lakes such as Pyramid Lake, Nevada, provide for a time integrated record of lake biology, chemistry, and depositional environment. This time integration minimizes the effects of large seasonal variations in productivity and nutrient availability on sediment composition allowing general spatial and historical trends to be examined.

Variations in the composition of lake sediments over time provide a historical record of lake productivity and nutrient loading. Although the composition of sediment particles may be altered after depo- sition (Berner, 1980), sediment composition at any depth below the sediment surface generally reflects the condition of the lake at the time of deposition. This includes both algal composition and nutrient content (Edmondson, 1991). For example, P stratigraphy has been shown in several lakes to reflect changes in basin development (Engstrom \& Wright, 1984), with elevated $\mathrm{P}$ content in sediments corresponding to periods of high P loading (Williams et al., 1976; Edmondson, 1991).

Lipid biomarker compounds have proved to be useful indicators of historical changes in organic matter accumulation in lake sediments. The combined distributions of sedimentary alkanes, fatty acids, alcohols, and sterols have enabled reconstructions of postglacial histories of organic matter deposition for Cam Loch, Scotland (Cranwell, 1977), Heart Lake, New York (Meyers et al., 1984), and Voua de la Motte, France (Wünsche et al., 1988). These lacustrine depositional 
histories include indications of changes in watershed vegetation, aquatic productivity, and organic matter preservation in bottom sediments.

In this paper, we examine historical trends in sediment composition at two locations in Pyramid Lake over the past 600-1000 years. Meyers et al. (1980) examined hydrocarbon and fatty acids contents of an undated core from the lake and showed that several important changes have occurred in past sources of organic matter to the system. These changes include modifications of both watershed conditions and lake productivity. Here, we present data on elemental and hydrocarbon content from dated cores of sediments in the center of the lake and near the mouth of Truckee River. Variations in the composition of modern sediments at those two locations are evaluated relative to the known history of watershed development and changes in water inflow to the lake. We then use the relationships derived from recent sediments to examine variations in sediment composition deeper in the cores.

\section{Methods and study site}

Study site

Pyramid Lake is a large $\left(450 \mathrm{~km}^{2}\right)$, terminal, hyposaline lake in western Nevada, USA (Fig. 1), with a total dissolved solids concentration of approximately $5400 \mathrm{mg} \mathrm{l}^{-1}$. The only permanent source of surface runoff to the lake, the Truckee River, arises in the Sierra Nevada mountains of eastern California and western Nevada. In transit, the Truckee passes through the city of Reno, and downstream of Reno, transbasin agricultural water diversion claims approximately $42 \%$ of total river flow (Milne, 1987). This diversion of water out of the watershed has led to cumulative decreases of $26 \%$ and $19 \mathrm{~m}$ in lake volume and level, respectively, between 1904 and 1992 (Fig. 2). The modem lake is $40 \mathrm{~km}$ long, and its width varies from $6.5 \mathrm{~km}$ at the south end to $16 \mathrm{~km}$ in the north. In July 1992, maximum and average depths were 102 and $60 \mathrm{~m}$, respectively.

Pyramid Lake is a warm, monomictic lake, although temporary meromixis can occur during periods of high Truckee River inflow. The lake mixes during winter (January-February) and is thermally stratified at 20-25 m between June-October (Galat et al., 1981; Lebo et al., 1992). The lake is highly alkaline (23 meq $\mathrm{l}^{-1}, \mathrm{pH}=9.1-9.3$ ), and its predominant ions are $\mathrm{Na}^{+}, \mathrm{Cl}^{-}$, and $\mathrm{HCO}_{3}^{-}-\mathrm{CO}_{3}^{2-}$ (Galat et al.,

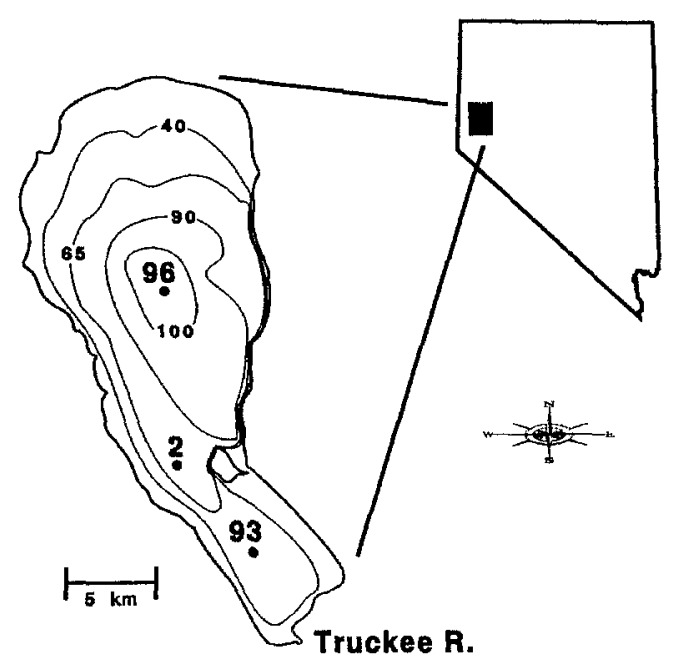

Fig. 1. Map of Pyramid Lake in relation to the state of Nevada, USA. Coring sites in the deep (96) and shallow (93) basins are shown as well as the site (2) for the core analyzed by Meyers et al. (1980). Approximate bathymetry (m) of the lake is also shown.

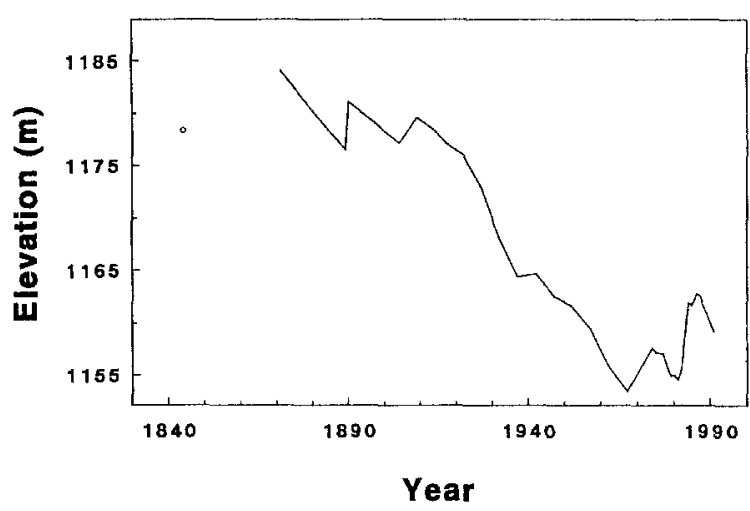

Fig. 2. Changes in lake level of Pyramid Lake. The open circle is an estimate of lake level when the lake was discovered by John Fremont (CDWR, 1991). Data are from the U.S. Geological Survey (Carson City, Nevada).

1981). At all times, Pyramid Lake is supersaturated with respect to aragonite (Galat \& Jacobsen, 1985), and precipitation of $\mathrm{CaCO}_{3}$ around surface springs is common.

As a desert lake, Pyramid is P-rich and $\mathrm{N}$-deficient (Hutchinson, 1937; Galat et al., 1981) with a dissolved inorganic elemental N:P ratio generally $<2$ (Reuter et al., 1993). The shores of the lake are sparsely vegetated and surrounded by mountains, and the lake is subject to intense dust storms, especially during spring. When compared with other saline lakes, Pyramid is oligotrophic with chlorophyll concentration typically $<3 \mu \mathrm{g} \mathrm{l}^{-1}$ (Galat et al., 1981; Lebo et al., 1992). 


\section{Methods}

Sediment cores were obtained in September 1991 with a General Oceanics Gravity Corer from the centers of the shallow and deep basins of Pyramid Lake (Fig. 1). Multiple cores were collected from both the deep (two) and shallow (three) basins. Cores were sectioned into discrete sediment horizons within two hours of collection. Sediment subsections were placed in pre-weighed disposable centrifuge tubes and weighed to determine total sediment wet weight. Subsections were then centrifuged, and part of the supernatant was removed for nutrient analyses of pore waters. After drying for one week at $60^{\circ} \mathrm{C}$, sediment subsections were reweighed to determine the dry weight of particulate material. Water content of sediments was calculated by subtracting dry weight from total wet weight and was used to estimate the porosity of sediments assuming a typical density of $2.46 \mathrm{~g} \mathrm{~cm}^{-3}$ for particles.

Concentrations of inorganic carbon $\left(\mathrm{CaCO}_{3}\right)$ in sediments were determined on one core from each location using a Coulometrics 5010 coulometer equipped with a 5030 carbonate carbon analyzer (cf. Engleman et al., 1985). In this instrument, $\mathrm{CaCO}_{3}$ is converted to $\mathrm{CO}_{2}$ by treatment with $\mathrm{HCl}$, and the amount of liberated $\mathrm{CO}_{2}$ is measured by titration in a monoethanolamine solution with a colorimetric indicator. Inorganic carbon concentrations were converted to weight percentages assuming all of the inorganic carbon present was in the form of calcium carbonate.

Total particulate $\mathrm{P}$ was measured by high temperature combustion $\left(500^{\circ} \mathrm{C}\right)$ followed by acid hydrolysis (Aspila et al., 1976; Solorzano \& Sharp, 1980). To insure complete recovery of particulate $P$, acid concentration and extraction time for the hydrolysis step were increased to $1 \mathrm{~N}$ and four hours, respectively. Recovery of $\mathrm{P}$ by this modified method was verified by perchloric acid digestion (Zasoski \& Burau, 1977). Inorganic particulate $\mathrm{P}$ was measured by excluding the combustion step from the total $P$ method. Organic particulate $P$ was calculated as the difference between total and inorganic $\mathrm{P}$. Precision for duplicate analysis of sediment $\mathrm{P}$ content was $2.6 \%(n=49)$.

Organic $\mathrm{C}$ content of sediments and organic matter $\mathrm{C}: \mathrm{N}$ ratios were determined in one core from each location by CHN analysis of samples which had been treated with $3 \mathrm{~N} \mathrm{HCl}$ to remove carbonate minerals. Measurements were made with a Carlo Erba 1108 CHNS analyzer. Organic $\mathrm{C}$ and $\mathrm{N}$ contents are reported on a whole-sediment basis.
Total lipid contents were extracted from dried sediment samples from the cores analyzed for organic $\mathrm{C}$ and $\mathrm{N}$ by sonication with dichloromethane. The hydrocarbon biomarker fractions were isolated from total lipids using alumina over silica gel columns (e.g. Leenheer et al., 1984). They were analyzed by on-column injection into a Hewlett-Packard 5890 gas chromatograph equipped with a $20 \mathrm{~m}$ DB1 capillary column. Quantification and identification of individual hydrocarbon components were achieved using internal standards added before extraction and FID response factors determined using quantitative mixtures of known compounds. Data have been corrected for the small amounts of procedural contaminants determined by blank analyses. In this paper, we restrict our presentation of biomarkers to the n-alkane $\mathrm{C}_{17}$ and $\mathrm{C}_{29}$ fractions which are indicators of algal and terrestrial sources of organic matter, respectively.

Nutrient concentrations in diluted pore waters collected by centrifugation were measured using standard colorimetric methods. Ammonium was measured by a modified indophenol reaction (Solorzano, 1969; Liddicoat et al., 1975) with a limit of detection (LOD) of $2 \mu \mathrm{g} \mathrm{N} 1^{-1}$. Nitrate + nitrite was measured by cadmium reduction using a shaking technique (Jones, $1984, \mathrm{LOD}=1 \mu \mathrm{g} \mathrm{N}^{-1}$ ). Phosphate was determined as reactive phosphorus (Strickland \& Parsons, 1972, $\left.\mathrm{LOD}=1 \mu \mathrm{g} \mathrm{P}^{-1}\right)$. Silica was measured as reactive silicate (Strickland \& Parsons, 1972, LOD $=50 \mu \mathrm{g} \mathrm{Si}$ $\left.1^{-1}\right)$.

The chronology of Pyramid Lake sediments was estimated using the decay of ${ }^{210} \mathrm{~Pb}$ to determine the net sediment accumulation rate. Measurements of ${ }^{210} \mathrm{~Pb}$ activity were made by $D$. N. Edgington at the University of Wisconsin at Milwaukee (Center for Great Lake Research) according to methodology specified in Robbins \& Edgington (1975). Dating chronologies were established for one core from both the shallow and deep basins. Because of low surficial values in Pyramid Lake sediments $\left(<0.15 \mathrm{~Bq} \mathrm{~g}^{-1}\right.$, Fig. 3), our selection of a model to interpret ${ }^{210} \mathrm{~Pb}$ profiles is limited by the sparse number of data points for each profile. For this reason, we have analyzed our data with a simple decay model assuming the ${ }^{210} \mathrm{~Pb}$ content of surficial sediments and sedimentation rate remain constant over time. Average sedimentation rates in the shallow and deep basins for 1880 -present indicated by our ${ }^{210} \mathrm{~Pb}$ profiles are 0.0470 and $0.0143 \mathrm{~g} \mathrm{~cm}^{-2} \mathrm{yr}^{-1}$, respectively.

We assigned dates to sediment horizons at the midpoint of mass. Samples from the tops of cores (depth 


\section{0-Pb (Bq g $\left.\mathrm{g}^{-1}\right)$}

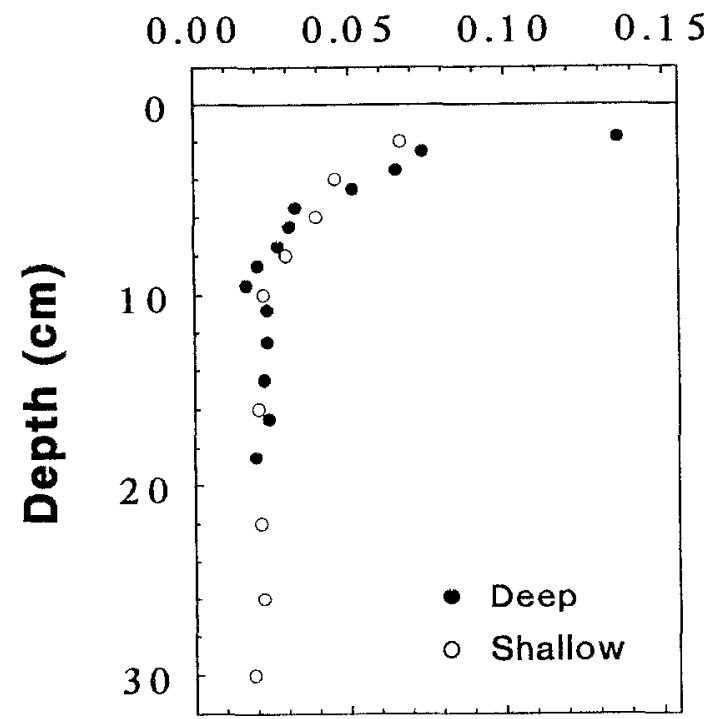

Fig. 3. Activity of ${ }^{210} \mathrm{~Pb}$ plotted versus depth for sediment cores collected from the deep and shallow basins of Pyramid Lake (see Fig. 1).

$<10 \mathrm{~cm}$ ) typically represent $11-15$ year periods while deeper sections $(>20 \mathrm{~cm})$ were sampled at larger depth intervals $(2-4 \mathrm{~cm})$ and represent periods of $30-60$ years. Thus, discussion of historical changes are limited to scales of decades and a century in the upper and lower portions of the sediment profiles, respectively.

\section{Results and discussion}

\section{Sediment description}

The tops of sediment cores at both locations were olivebrown indicating oxidized surficial sediments. However, the depth of oxidized surficial sediments in our cores was less than observed for similar locations during a synoptic survey of surficial sediments; Ekman grabs from the centers of the deep and shallow basin indicated several centimeters of olive brown sediment compared with $<1 \mathrm{~cm}$ for sediment cores (M. E. Lebo unpubl. data). Crusius \& Anderson (1991) reported the loss of a large fraction $(5-15 \mathrm{~cm})$ off the top of sediment cores collected by gravity corer, and it may be that the upper $1-2 \mathrm{~cm}$ of short $(<50 \mathrm{~cm})$ cores and as much as $4 \mathrm{~cm}$ from the longer $(>1 \mathrm{~m})$ core at station 93 were also lost. To account for these apparent losses, we have adjusted the depth of sediment horizons in our analyses to reflect surficial sediment losses of 1.0 and $1.5 \mathrm{~cm}$ for short cores from the shallow and deep basin cores, respectively. The longer core from station 93 was adjusted by $3.5 \mathrm{~cm}$. Because the actual loss is unknown, uncertainty in the dates assigned to sediment horizons due to surficial sediment loss is probably ten years.

Sediments below the oxidized surficial layer were black and smelled of $\mathrm{H}_{2} \mathrm{~S}$, indicating anoxia. Below the subsurface black layer, there was a transition from black to gray in all cores, with the change occurring at 10 and $14 \mathrm{~cm}$ in the deep and shallow basins, respectively. This transformation from black to gray corresponds to the 1870 depositional horizon at both sites. Sediments in the lower portions of all cores were uniformly gray.

Water content of sediments was highest near the sediment surface and decreased with depth (Fig. 4). In the shallow basin, the simple pattern of increasing porosity of sediments toward the surface is complicated by a relative minimum during 1950-1970. This minimum in near surface sediments of the shallow basin indicates a shift in either the sources of particulate matter or depositional environment at that time. The difference in the water content of sediments between the two coring sites can be attributed to spatial variations in the grain size distribution of sediments in Pyramid Lake (Fig. 5). Initial water content of sediments is primarily a function of sediment grain size, with increasing porosity as particles get smaller (Berner, 1980). Therefore, smaller particles $(<5 \mu \mathrm{m})$ make up a larger proportion of total mass in the deep basin $(23.8 \%)$ compared with the shallow station (17.2\%), leading to higher porosity in the center of the lake. In fact, the observed difference in grain size distributions between basins is part of a general spatial pattern for surficial sediments of Pyramid Lake, with decreasing grain size as water column depth increases (M. E. Lebo, unpubl. data). Factors probably contributing to this pattern are Truckee River sediment loading to the shallow basin and preferential deposition (focusing) of fine particles to the deep regions of the lake.

\section{$\mathrm{CaCO}_{3}$ accumulation patterns}

The $\mathrm{CaCO}_{3}$ content of sediments in Pyramid Lake is higher in the center of the lake than in the shallow basin (Fig. 4). This difference in the $\mathrm{CaCO}_{3}$ content of sediment between the basins can probably be attributed to the input of low $\mathrm{CaCO}_{3}$ particulate matter from 


\section{$\operatorname{CacO3}(\%)$}

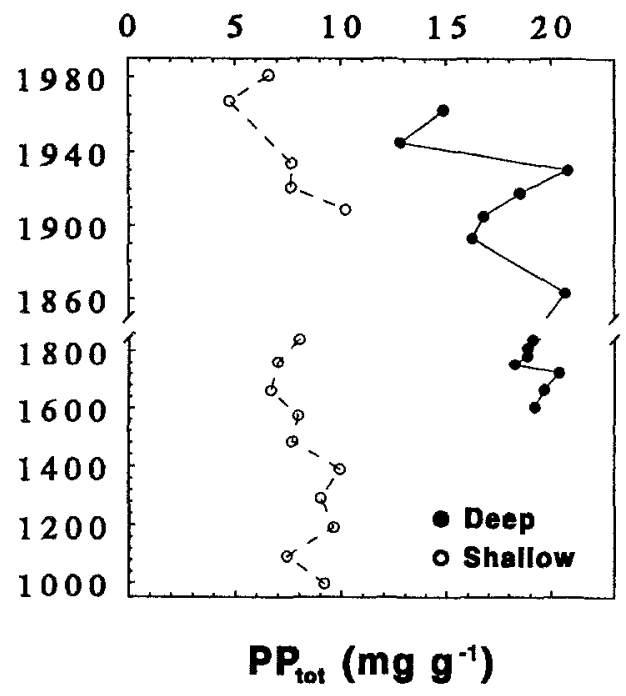

\section{Water Content (\%)}
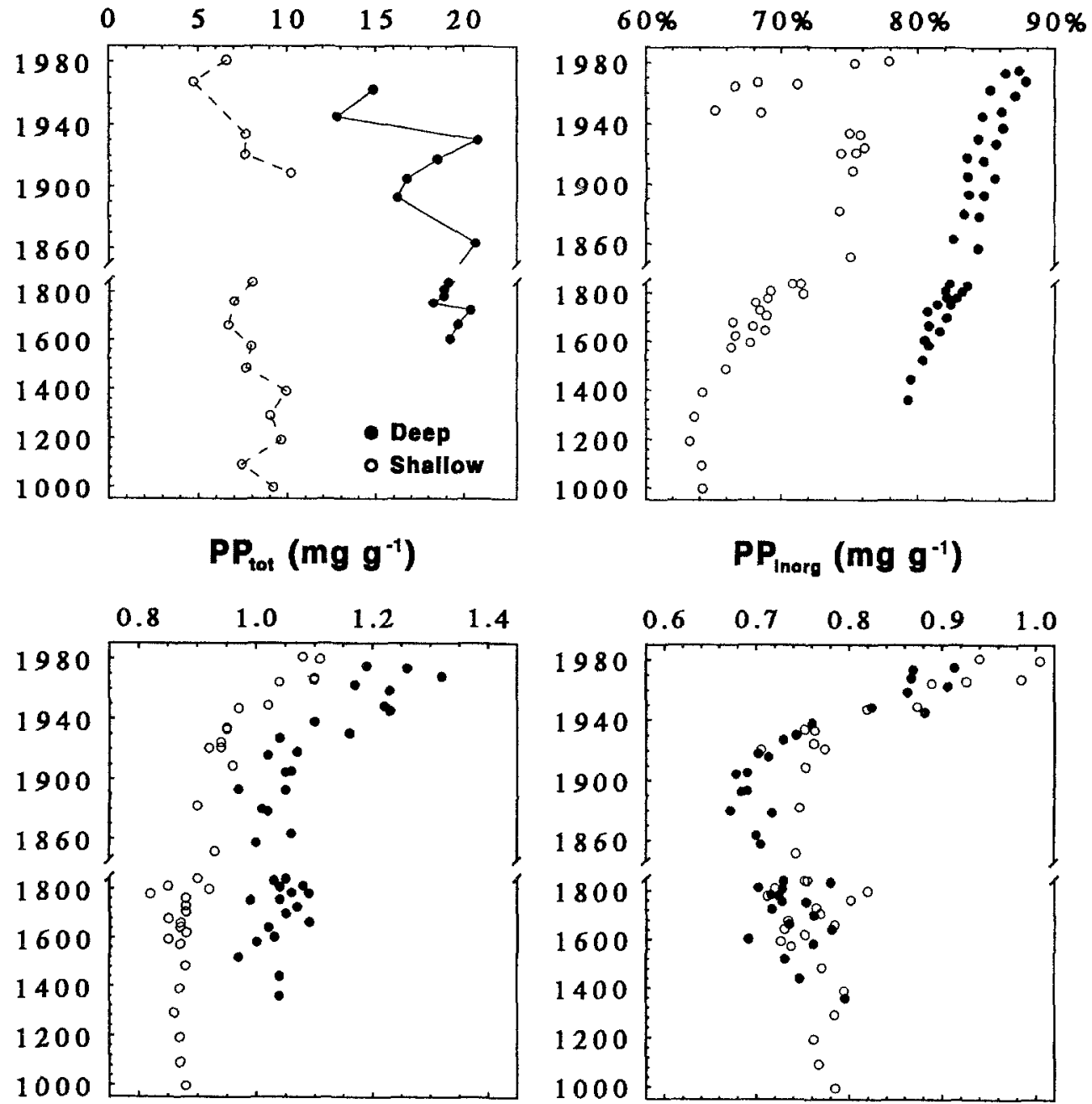

Fig. 4. Variations in sedimentary $\mathrm{CaCO}_{3}$, water, total $\mathrm{P}\left(\mathrm{PP}_{t o t}\right)$, and inorganic $\mathrm{P}\left(\mathrm{PP}_{\text {inorg }}\right)$ content in Pyramid Lake. Fractions are plotted by date of deposition extrapolated from ${ }^{210} \mathrm{~Pb}$ sediment accumulation rates. $\mathrm{CaCO}_{3}$ data are from one core at each location while data for the other fractions are from all cores collected. Note the break in the date scale.

the Truckee River into the shallow basin. Indeed, a synoptic sampling of surficial sediments of Pyramid Lake revealed a pronounced south-north gradient in $\mathrm{CaCO}_{3}$ content with lowest values $(<10 \%)$ near the mouth of Truckee River compared with $\mathrm{CaCO}_{3}$ content $>15 \%$ throughout the deep basin (Lebo \& Reuter, in press). Further, a composite of two river water samples collected in May 1993 during peak flow (and sediment load) indicated suspended sediment was $7.3 \% \mathrm{CaCO}_{3}$ by weight (M. E. Lebo, unpubl. data).

Sediment focusing may also contribute to the observed spatial pattern. Galat \& Jacobsen (1985) reported that 'whiting' events (e.g. precipitation of
$\mathrm{CaCO}_{3}$ in surface waters) are a recurrent feature in Pyramid Lake, and it is likely that a majority of $\mathrm{CaCO}_{3}$ deposited in the sediments is produced during these events. Because $\mathrm{CaCO}_{3}$ crystals formed during whiting events are generally small $(\sim 5 \mu \mathrm{m}$, Galat \& Jacobsen, 1985), the focusing of fine particles to the deeper regions of Pyramid Lake would contribute to an enrichment in the $\mathrm{CaCO}_{3}$ content of sediments from the center of the lake.

The fluctuations in $\mathrm{CaCO}_{3}$ content of sediments in the shallow basin are probably linked to changes in Truckee River inflow. In the shallow basin, $\mathrm{CaCO}_{3}$ content was lowest in the 1967 horizon (Fig. 4) con- 


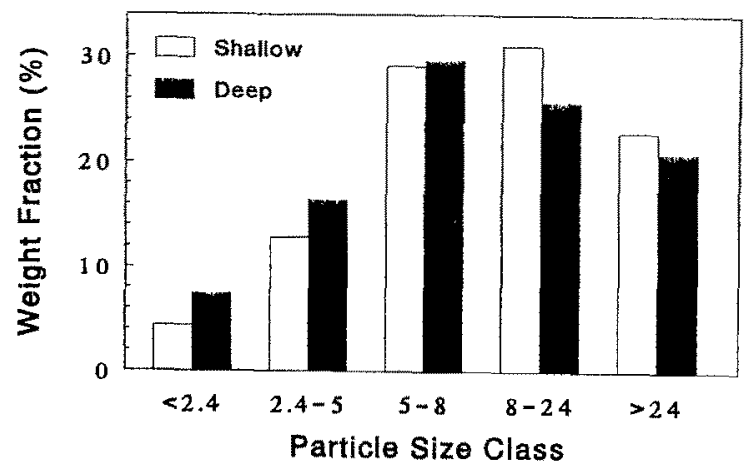

Fig. 5. Particle size distribution $(\mu \mathrm{m})$ for surficial sediments from the centers of the shallow and deep basins of Pyramid Lake.

current with the historical low stand for Pyramid Lake (Fig. 2) and increased with depth to the 1909 horizon. In the deeper portions of cores taken from the shallow basin, there were additional minima at 1660 and 1093 . It is noteworthy that the large decline in the $\mathrm{CaCO}_{3}$ content of sediments in the shallow basin during the 1900 's (e.g. Fig. 4) corresponds to a period when $42 \%$ of total Truckee River flow was diverted for agriculture (Milne, 1987) and lake level declined rapidly (Fig. 2). This suggests that the magnitude of river inflow to Pyramid Lake affects the $\mathrm{CaCO}_{3}$ content of sediments in the shallow basin. We can only speculate on the mechanism, but it may be that the efficiency of the redistribution of fine autochthonous particles (e.g. precipitated $\mathrm{CaCO}_{3}$ ) increases with decreasing lake level (see below).

The apparent correspondence between river inflow and the $\mathrm{CaCO}_{3}$ content of sediments in the shallow basin is contrasted by a peak in the $\mathrm{CaCO}_{3}$ content of sediments in the center of the lake in the 1930 horizon (Fig. 4). This corresponds to a period when lake level was rapidly declining. It is interesting that additional peaks in the $\mathrm{CaCO}_{3}$ content of sediments in the center of the lake occurred in the 1863 and 1755 horizons. Examination of a dendrochronology for Donner Summit reconstructed from Jeffrey Pine reveals that the 1930's, 1860's, and mid-1700's were all periods of poor growth (Fig. 6). This suggests that water availability during those three periods was low, indicating below-normal snow accumulation in the mountains that feed Truckee River. Thus, the observed peaks in $\mathrm{CaCO}_{3}$ content of bottom sediments in the center of the lake occurred during one period of known lake level decline and two periods of probable decline. This suggests that decreasing lake volume during periods

\section{Growth Index}

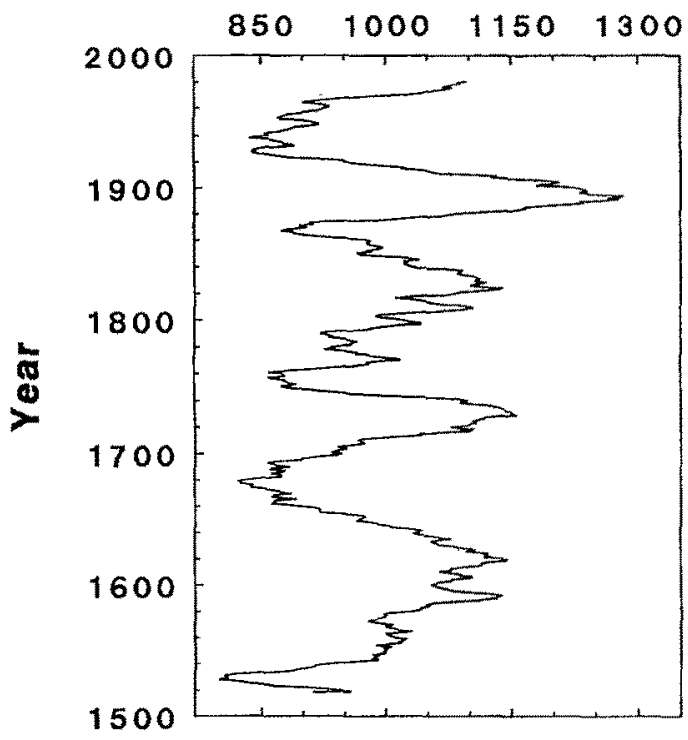

Fig. 6. Dendrochronology for Donner Summit constructed from Jeffrey Pine. Values are 20 -year moving averages to approximate sediment horizon intervals. A growth index of $<1000$ represents poor growth conditions indicating possible drought conditions. Data are from Marty Rose (Univ. Nevada, Reno).

of low inflow actually increases the $\mathrm{CaCO}_{3}$ content of sediments in the center of the lake.

Two factors probably contribute to the observed increase in sedimentary $\mathrm{CaCO}_{3}$ in the center of the lake during drought periods: decreased terrestrial inputs and stimulation of 'whiting' events. During drought periods, Truckee River inflow is reduced which causes a corresponding decrease in river sediment loading to the lake. The spatial pattern of $\mathrm{CaCO}_{3}$ content of surficial sediments in Pyramid Lake indicates that Truckee River sediment loading is low in $\mathrm{CaCO}_{3}$, and thus, the non- $\mathrm{CaCO}_{3}$ terrestrial component of sedimentation should be reduced during drought periods. Additionally, the $\mathrm{Ca}^{2+}$ concentration of the lake should increase during drought periods as lake volume decreases due to evaporation. Because the timing of whiting events in Pyramid Lake is dependent on increases in the $\mathrm{Ca}^{2+}$ concentration (Galat \& Jacobsen, 1985; M. E. Lebo unpubl. data), extended drought periods should stimulate whiting events. These two factors would both contribute to a greater proportion of $\mathrm{CaCO}_{3}$ in sediments deposited in the center of the lake during drought periods. 


\section{Sediment phosphorus}

Sedimentary P in Pyramid Lake is elevated near the surface and then decreases to relatively constant values in deeper portions of the sediment cores (Fig. 4). In the shallow basin, sediment $P$ was $1.1 \mathrm{mg} \mathrm{g}^{-1}$ near the surface and decreased to $0.88 \pm 0.02 \mathrm{mg} \mathrm{g}^{-1}$ by the mid-1800's. A similar trend was also true in the deep basin; sediment $\mathrm{P}$ was $>1.2 \mathrm{mg} \mathrm{g}^{-1}$ at the surface and decreased with depth to $1.05 \pm 0.05 \mathrm{mg} \mathrm{g}^{-1}$ by the early 1900 's. When the depth distributions for the inorganic fraction of sedimentary $\mathrm{P}$ are compared with those for total $P$, the surface enrichment in $P$ can be attributed to an increase in inorganic phases; the surface enrichment in total $P$ in both basins coincided with an enrichment of similar magnitude in sedimentary inorganic $P$. The similarity between the depth trends in both fractions, however, is limited to the past century. Below the zone of surficial enrichment, inorganic sedimentary $\mathrm{P}$ decreased to a relative minimum in the deep basin around 1900 before increasing with depth in the deeper portions of cores from that location. In contrast, inorganic sedimentary $\mathrm{P}$ was relatively constant at $0.76 \pm 0.03$ (mean \pm std.dev.; $n=22$ ) in sediments prior to 1900 in the shallow basin. The difference in total $P$ content between the basins is due to higher sedimentary organic $\mathrm{P}$ in the center of the lake compared with the shallow site (see below).

The large proportion of sedimentary $\mathrm{P}$ associated with inorganic phases is typical in lake sediments, with $\mathrm{P}$ associated mainly with iron, aluminum, and calcium mineral phases (Williams et al., 1971, 1976; Klapwijk \& Bruning, 1986; Ostrofsky, 1987). The surface enrichment of inorganic $P$ that we observed in Pyramid Lake (e.g. Fig. 4) has also been reported in other lakes (Sasseville \& Norton, 1975; Kemp et al., 1976; Engstrom, 1983). However, elevated inorganic $\mathrm{P}$ in surficial sediments of lakes has generally been attributed to the binding of phosphate in ferric iron phases (Engstrom \& Wright, 1984), which is probably not applicable at the high pH (9.1-9.3) in Pyramid Lake waters. This is due to the release of $P$ from ferric oxyhydroxides in alkaline waters (e.g. Stumm \& Morgan, 1981). Indeed, sediments from Pyramiid Lake have a limited capacity to adsorb P (Lebo et al., 1994) indicating inorganic sedimentary $\mathrm{P}$ is probably associated with calcium phases (e.g. $\mathrm{CaCO}_{3}$ ). The surface enrichment in sedimentary $\mathrm{P}$ is probably due to an increased sedimentary flux of $\mathrm{P}$ in the 1900's.

\section{Organic fractions}

The organic content of sediments from the deep basin showed peaks during two time periods (Fig. 7). Overall, the organic content of sediments was higher at the deep site than in the shallow basin. Lebo \& Reuter (in press) showed that this spatial difference between sites is part of a general pattern for sediments in Pyramid Lake with total $\mathrm{C}$ and organic $\mathrm{N}$ and $\mathrm{P}$ all significantly $(\mathrm{P}<0.001)$ correlated with station depth $(n=23$ sites). In the deep basin, the distributions of sedimentary organic C and N showed sharp peaks in the 1945 horizon, while a similar peak occurred somewhat deeper (e.g. 1930) for organic P. A second broad peak was observed for organic $\mathrm{C}$ and $\mathrm{N}$ between 1811 and 1863 . Prior to the 1800 's, the organic content of sediments in the deep basin generally decreased with depth. It is noteworthy that the organic content at the sediment surface in the deep basin is probably higher than indicated by our sediment core data. Lebo \& Reuter reported that average total $\mathrm{C}$ and organic $\mathrm{N}$ and $\mathrm{P}$ for nine samples collected at stations with a bottom depth $>90 \mathrm{~m}$ were $54,4.6$, and $0.48 \mathrm{mg} \mathrm{g}^{-1}$, respectively. Thus, a third peak in sediment organic content probably occurred at the sediment surface but was lost during sampling.

In the shallow basin, the organic content of sediments also showed two peaks (Fig. 7). However, the peaks in sedimentary organic $\mathrm{C}, \mathrm{N}$, and $\mathrm{P}$ in the shallow basin did not occur during the same time periods as those observed for deep basin sediments. The peaks in organic content of sediments in the shallow basin occurred at the surface (1981) and around 1900, with only minimal surface enrichment in organic P. However, Lebo \& Reuter (in press) reported an average organic P content of $0.34 \mathrm{mg} \mathrm{g}^{-1}(n=4)$ in the center of the shallow basin indicating the surface enrichment in sedimentary organic P may have been lost during core collection. In contrast to the peaks in the organic content of recent sediments, all three organic fractions were low and relatively constant in sediments prior to 1800.

The elemental ratios of sedimentary organic matter in both basins showed several distinct changes associated with variations in organic $C, N$, and $P$ (Fig. 7). In the deep basin, the relative $\mathrm{N}$ and $\mathrm{P}$ content of organic matter both showed a peak in the 1930 horizon indicated by minima in the $\mathrm{C}: \mathrm{N}, \mathrm{C}: \mathrm{P}$, and $\mathrm{N}: \mathrm{P}$ ratios. Additionally, elemental composition prior to 1800 showed a progressive increase in $\mathrm{C}: \mathrm{N}$ ratio and decreases in $\mathrm{C}: \mathrm{P}$ and $\mathrm{N}: \mathrm{P}$ ratios. Changes in elemental ratios in the shallow basin generally reflected variations in organic 

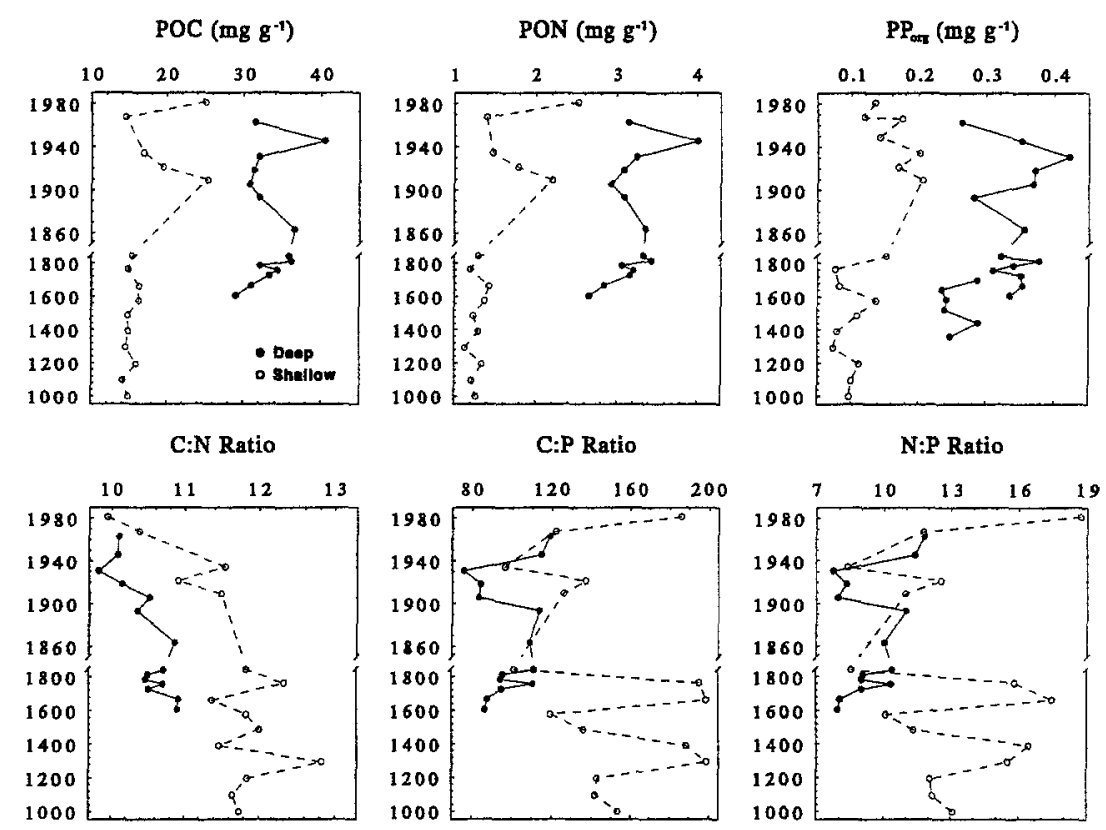

Fig. 7. Variations in Pyramid Lake sedimentary organic C (POC), $\mathrm{N}(\mathrm{PON})$, and $\mathrm{P}\left(\mathrm{PP}_{\mathrm{org}}\right.$ ) fractions and nutrient ratios of organic matter by date of deposition (see Fig. 4).

$\mathrm{C}$ and $\mathrm{N}$ after 1900 but organic P prior to 1800 . At the surface, the $\mathrm{C}: \mathrm{N}$ ratio of organic matter was lowest at a value of $<10$, and then it generally increased with depth to values of $11.32 \pm 0.35$ (mean \pm std.dev) for the 1909 to 1934 horizons $(n=3)$ and $11.89 \pm 0.42$ prior to $1840(n=10)$. For sedimentary organic $\mathrm{P}$ ratios, variations after 1900 followed changes in organic $\mathrm{C}$ and $\mathrm{N}$, such as the pronounced surface enrichment in those fractions. The C:P and $\mathrm{N}: \mathrm{P}$ ratios in sediment of the shallow basin deposited prior to 1800 , however, reflected variations in organic $P$, with maxima observed in the 1291 and 1660-1761 horizons.

The elemental composition of organic matter in sediments can help determine past sources of organic matter to lakes. Because the presence or absence of cellulose influences the $\mathrm{C}: \mathrm{N}$ ratio of plant material, detrital organic matter deposited in sediments can vary in $\mathrm{C}: \mathrm{N}$ depending on its source. Generally, nonvascular aquatic plants (e.g. phytoplankton) have low C:N ratios, typically between 4 and 10 , whereas vascular land plants, which contain cellulose, have C:N ratios of 20 and greater (e.g. Meyers \& Ishiwatari, 1993). Although selective degradation of organic matter components during early diagenesis can modify elemental compositions and hence $\mathrm{C}: \mathrm{N}$ ratios of organic matter in sediments, burial in lake bottoms appears to stabilize organic matter $\mathrm{C}: \mathrm{N}$ ratio to further diagenetic alter- ation (Meyers, 1994). For this reason, downcore C:N profiles can be interpreted in terms of past histories in the proportions of aquatic and terrestrial plant debris which has been delivered to lake sediments.

The C:N values in sediment cores from the shallow and deep basin allow several observations about the sources of organic matter to the sediments at these locations. First, both algae and land plants contribute organic matter to the sediments of Pyramid Lake, based on $\mathrm{C}: \mathrm{N}$ ratios between 10 and 13 (Fig. 7). The relatively low ratios further indicate that algal sources dominate, particularly in modern sediments. Second, the ratios are higher at the shallower site, indicating that this location receives more land-derived organic matter because of its closer proximity to the mouth of the Truckee River. Third, C:N ratios increase with sediment age at both locations. This pattern records higher proportions of land-derived organic matter in the past and a shift to a progressively larger fraction of algal material since the late 1800 's.

Compositions of $n$-alkane biomarkers indicate that the majority of the hydrocarbons preserved in sediments of both basins is of terrestrial origin. Generally, the $\mathrm{C}_{29}$ fraction (land plants) was often tenfold higher than the $\mathrm{C}_{17}$ fraction which represents phytoplankton production (Fig. 8). The dominance of the land-derived biomarkers over the algal biomarker contrasts with 
the $\mathrm{C}: \mathrm{N}$ results which indicate that algal contributions dominate bulk organic matter in the lake sediments. The over-representation of land-plant biomarkers is common in sediments of other lakes as well due to a higher proportion of n-alkanes in organic matter from terrestrial origin (e.g. Meyers \& Ishiwatari, 1993). Spatially, $\mathrm{C}_{29}$ hydrocarbons were higher in the shallow basin while $\mathrm{C}_{17}$ hydrocarbons were higher in the center of the lake. This spatial pattern is consistent with the $\mathrm{C}: \mathrm{N}$ patterns, indicating both a terrestrial source of $\mathrm{C}_{29}$ hydrocarbons to the shallow basin and focusing of the $\mathrm{C}_{17}$ fraction to the center of the lake. In addition, the relative contributions of $\mathrm{C}_{29}$ and $\mathrm{C}_{17}$ fractions reported here are similar to previous measurements of those fractions in Pyramid Lake sediments (Meyers et al., 1980).

Variations in the hydrocarbon biomarkers with depth in the sediments of Pyramid Lake support changes in productivity and river sediment loading over the past 1000 years. In both basins, the $C_{17}$ hydrocarbon fraction demonstrated a surface peak (Fig. 8) indicating a period of relatively high productivity in the lake in recent years. Additional peaks in the $\mathrm{C}_{17}$ fraction occurred in the 1918 horizon in the deep basin and throughout the horizons from 1100-1400 in the shallow basin. For the $\mathrm{C}_{29}$ fraction, values in the deep basin increased with depth for sediments after 1900 and prior to 1800 , with a minimum in 1863 between maxima in the 1893 and 1603 horizons. In the shallow basin, the $\mathrm{C}_{29}$ fraction showed peaks in the 1934 , 1483 , and 996 horizons indicating that river loading of terrestrial carbon was probably high at those times.

\section{Pore water nutrients}

Nutrient concentrations in sediment pore waters of Pyramid Lake generally increased with depth (Fig. 9). Benson (1984) reported depth distributions for phosphate and silicate in pore waters of sediments cores collected from five locations in Pyramid Lake, and our results presented here are identical to that study. In the deep basin, profiles of phosphate and ammonium both increased exponentially with depth, as has been typically reported for aquatic sediments (e.g. Carignan \& Lean, 1991). In contrast, ammonium and phosphate pore water concentrations in shallow basin sediments showed different depth trends; although the concentration of ammonium showed a continual increase with depth, there was a subsurface maximum in phosphate with lower concentrations in sediments deposited prior to 1800 . Silica concentration in pore waters increased rapidly with depth in both basins to values $>25 \mathrm{mg}$ Si $1^{-1}$ within $50-70$ years after deposition. It is noteworthy that the silica concentrations in pore waters of Pyramid Lake sediments prior to 1920 are identical to equilibrium values with respect to biogenic silica reported for deep ocean sediments (Broecker \& Peng, 1982). Finally, nitrate concentration, in contrast to other nutrient fractions, was low $\left(<0.12 \mathrm{mg} \mathrm{l}^{-1}\right)$ throughout the sediment column of both basins accounting for $<1 \%$ of dissolved inorganic $\mathrm{N}$.

There are three possible explanations for the phosphate profile observed in the shallow basin: (1) formation of a $\mathbf{P}$ mineral in deeper sediments, (2) groundwater input to the shallow basin, or (3) a change in source of particulate matter to shallow basin sediments in recent years. Berner (1980) presented a theoretical scenario whereby phosphate concentrations can be reduced in deeper sediment horizons through the formation of a mineral phase containing P. For this explanation to be plausible in Pyramid Lake, the pore water chemistry in the shallow basin must be distinctly different from the center of the lake to promote mineral formation in one location but not the other. However, the composition of pore waters in the shallow basin is similar to the center of the lake. Benson (1984) reported that $\mathrm{pH}$, redox potential, calcium concentration, and dissolved iron were nearly identical in the deeper $(>50 \mathrm{~cm})$ portions of sediments at both locations.

The possibility of large amounts of groundwater input in the shallow basin can also be dismissed after comparing the major ion composition of pore waters from both locations. If groundwater were coming into the shallow basin to a greater extent than the rest of the lake, conservative tracers such as sodium and chloride should be more diluted in the deeper portions of sediments from the shallow basin. This is not the case. Indeed, Benson (1984) reported similar depth trends in sodium and chloride concentrations for five cores taken at different locations around the lake, which is inconsistent with the preferential input of groundwater to the shallow basin.

We are left, therefore, with a change in the sources of particulate matter deposited in the shallow basin beginning around 1600 . Sedimentary $P$ provides some evidence to suggest a change in $\mathrm{P}$ inputs to the lake; in the same depth horizon that phosphate increased, sedimentary $\mathrm{P}$ may also have shown a small increase. However, strong evidence for change is lacking in our data set. 


\section{n- $\mathbf{C}_{17}$}

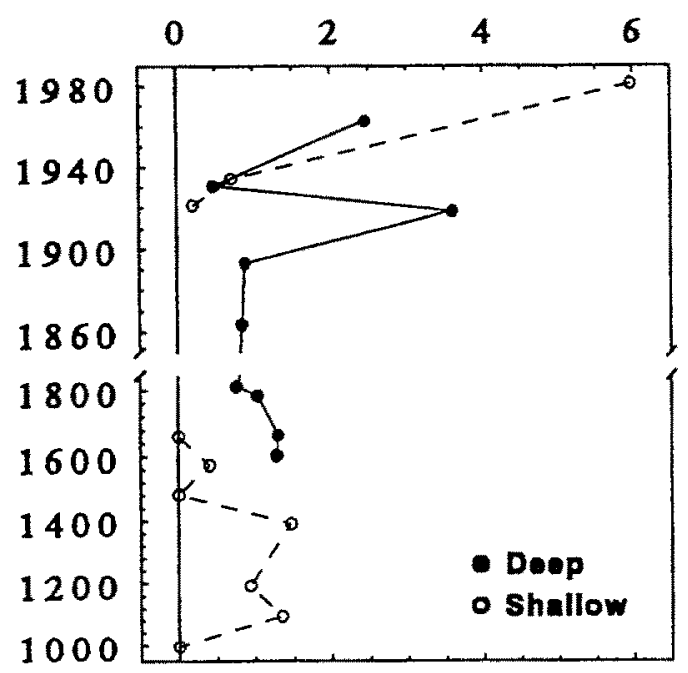

$\mathbf{n}-\mathbf{C}_{29}$

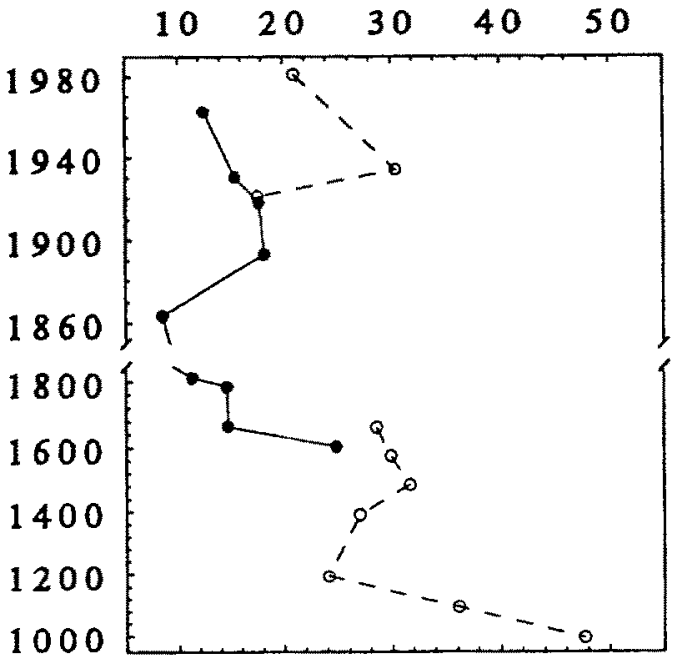

Fig. 8. Variations in n-alkane $C_{17}$ and $C_{29}$ fractions in Pyramid Lake sediments by date of deposition (see $F$ ig. 4). $n-C_{17}$ and $n-C_{29}$ units in micrograms per gram.

\section{Productivity changes}

Sediment composition and nutrient depth profiles indicate potential variations in the productivity of Pyramid Lake over the past 1000 years. Meyers et al. (1980) in previous work at the lake reported that the contribution of phytoplankton production within the lake to total sedimentary organic matter was greatest in the upper $30 \mathrm{~cm}$. The authors also identified an apparent shift in the trophic state or level of phytoplankton production in Pyramid at some time in the past. The date of this apparent shift to increased phytoplankton production was estimated to have occurred around 1300-1400. In this section, we utilize variations in sedimentary organic fractions, n-alkane biomarkers, and pore water nutrients in the cores collected from Pyramid Lake to evaluate potential changes in the historical level of phytoplankton production.

Sediment cores from the deep basin provide evidence for a period of increased productivity in Pyramid Lake during 1893 to 1945 (Figs. 7-8). In that period, organic C and N (1945) and P (1930) all showed peaks, which suggests an increase in lake productivity. A period of higher productivity is also supported by changes in the elemental composition of organic matter. Concomitant with increasing organic content of sediment was decreasing $C: N, N: P$, and $C: P$ ratios, with the values observed during the early 1900's characteristic of phytoplankton biomass. Additionally, the n-alkane data showed a peak in the $C_{17}$ fraction in the 1918 horizon. Thus, biomarker, organic fractions, and elemental composition of organic matter data all indicate a period of increased productivity in Pyramid Lake during the early 1900's.

A comparison of changes in the organic content of sediment in the deep basin during the early $1900^{\circ} \mathrm{s}$ and pore water nutrients also supports increased productivity at that time. Because organic matter in sediment is continually remineralized by bacteria (e.g. Berner, 1980; Carignan \& Lean, 1991), the apparent increases in organic fractions during 1893-1945 may be due to greater total degradation in older sediments (e.g. 1893 vs. 1945). The buildup of nutrients in pore waters, thus, provides an estimate of the amount of organic matter remineralized between different sediment horizons. One problem with this mass balance approach to sediment nutrient dynamics is that it underestimates the total diagenetic production of nutrients due to diffusion of nutrients toward the sediment surface. However, large discrepancies between expected and observed pore water nutrients does provide indirect support for increased productivity.

Large increases $(29-45 \%)$ in organic $P$ and $N$ in sediments from the deep basin occurred between 1893 and 1945 . We can estimate the fraction of these increases for which the breakdown of organic matter between 1945 and 1893 can account through changes in pore water nutrient concentrations. Between the 1945 and 


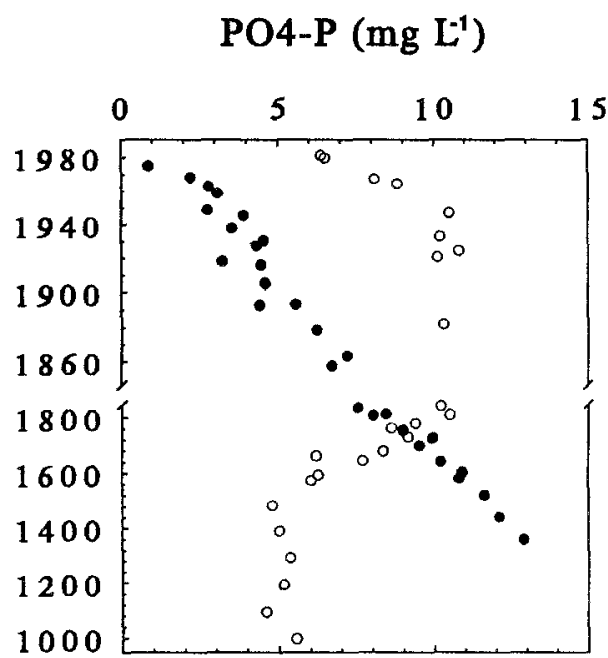

SiO2-Si (mg L'-1)

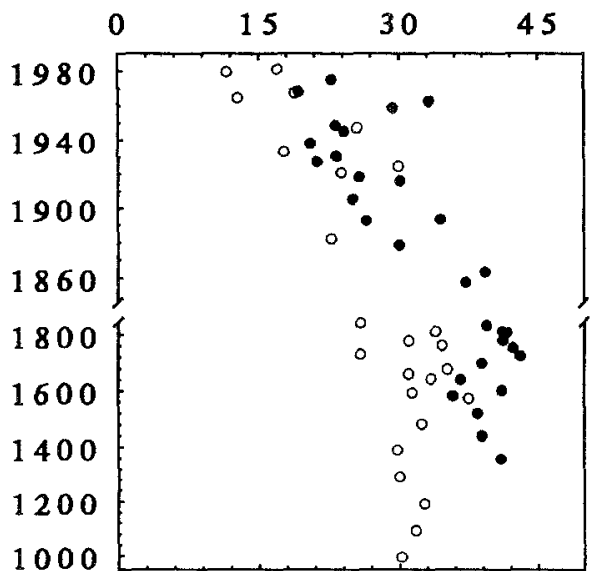

NH4-N (mg L-1)
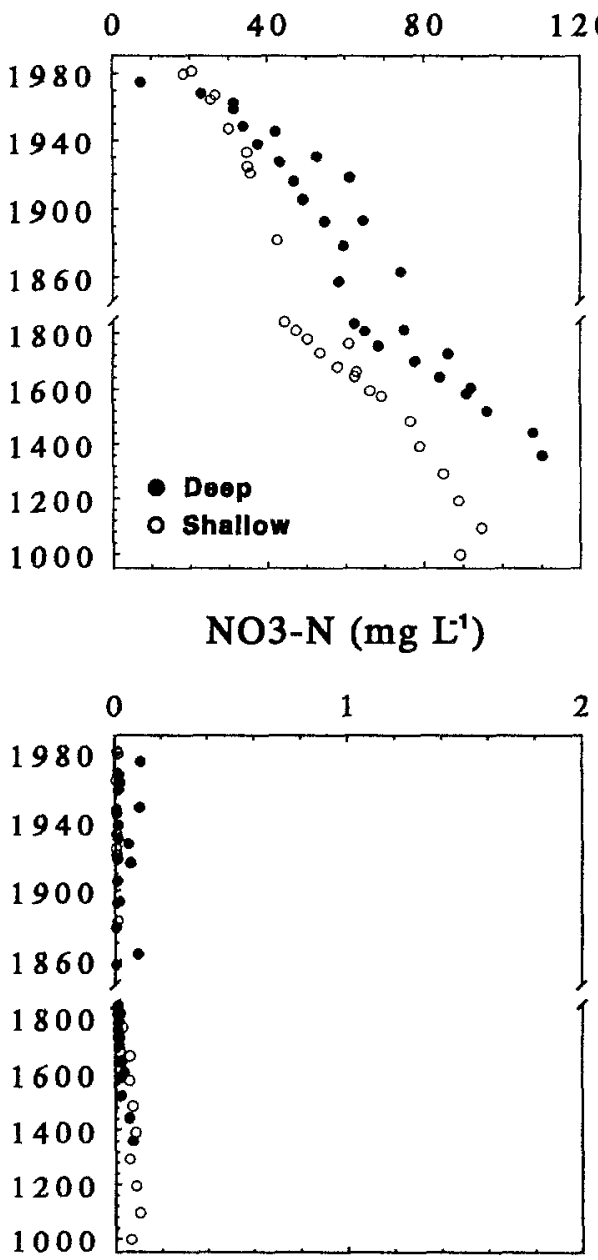

Fig. 9. Variations in phosphate (PO4-P), ammonium (NH4-N), silicate (SiO2-Si), and nitrate (NO3-N) in pore waters of Pyramid Lake sediments by date of deposition (see Fig. 4). Data are shown for all cores collected.

1893 sediment horizons, phosphate and ammonium concentrations in sediment pore waters increased by approximately 1.7 and $23 \mathrm{mg}^{-1}$, respectively. Using the porosity for sediments from that time period and a typical density of $2.46 \mathrm{~g} \mathrm{~cm}^{-3}$ for particles, the observed changes in phosphate and ammonium concentrations indicate the breakdown of 0.01 and $0.13 \mathrm{mg}$ $\mathrm{g}^{-1}$ of organic $\mathrm{P}$ and $\mathrm{N}$, respectively. However, the observed decreases in sedimentary organic $\mathrm{P}$ and $\mathrm{N}$ over the same time period were 0.13 and $0.9 \mathrm{mg} \mathrm{g}^{-1}$, respectively. Thus, increases in pore water nutrients can account for only 8-14\% of the apparent decreases in sedimentary organic P and N during 1945 to 1893 supporting increased production during that time period.
Changes in the organic content of deep basin sediments with depth also suggest an increase in the productivity of Pyramid Lake during 1600-1700. During that century, organic $\mathrm{N}$ and $\mathrm{P}$ both increased by $19 \%$ (Fig. 7). When these changes are compared with the observed changes in phosphate and ammonium in pore waters over the same period ( 1.3 and $13 \mathrm{mg} \mathrm{l}^{-1}$, respectively), the breakdown of sedimentary organic $\mathrm{P}$ and $\mathrm{N}$ can only account for $11-13 \%$ of the apparent increases. This suggests that the 1600-1700 period, similar to 1893-1945, may have experienced increased productivity in Pyramid Lake. However, the 1600-1700 period was also a time when river sediment loading to the lake was probably reduced due to low inflow (inferred from tree growth, Fig. 6). Thus, an alternative 
explanation to increased algal productivity in Pyramid Lake during the 1600's is that there was lower inorganic sediment loading from Truckee River to the lake at that time. This would increase the relative contribution of algal production to new sediment accumulation.

Finally, Meyers et al. (1980) suggested that the trophic status of Pyramid Lake changed around 13001400 from oligotrophic to mesotrophic conditions. We can examine evidence for this change in trophic state in sediments from the shallow basin. It is noteworthy that the time period for which Meyers et al. suggested increased productivity corresponds to a broad peak in the sedimentary $n$-alkane $\mathrm{C}_{17}$ fraction in the shallow basin (Fig. 8). Thus, our data corroborates a period of potentially increased productivity in Pyramid Lake during 1100-1400. However, that period of potentially increased productivity in Pyramid Lake was followed by low values for the $\mathrm{C}_{17}$ fraction in sediments from the shallow basin until the late 1900's. This indicates that the apparent increased productivity of the 1100-1400 period was not a permanent shift in the trophic status of the lake but rather a prolonged period of higher productivity.

\section{Impacts of development}

The recorded history of development within the Truckee River basin includes major changes to the landscape of the region and hydrology of the river itself. Permanent settlements were first established in the region between 1849 and 1859 , but it was the discovery of the Comstock silver Lode that transformed the Truckee River basin from wilderness to an urban environment (Townley, 1980). By the 1870 's, it is estimated that 25 lumber mills operated along the upper reaches of the Truckee River to support the timber needs of mining operations (CDWR, 1991). Further, the logging debris discharged to the river from these mills hindered fish migrations and at one point (1874) actually blocked access to the river from Pyramid Lake (Townley, 1980). A second event which dramatically altered the Truckee River system was the completion in 1905 of Derby Dam $65 \mathrm{~km}$ upstream from Pyramid Lake. As part of the first land reclamation project in the United States, the operation of the dam has deprived Pyramid Lake of a large portion ( $>40 \%$ ) of its historic inflow (Milne, 1987). Finally, the development of Reno as an urban center, particularly after 1950 , contributed large sewage discharges to the river further degrading water quality (Townley, 1980).
The beginning of development in the Truckee River basin, 1860-1900, was marked by several changes in the sediment composition of Pyramid Lake. Visually, the transition in sediment color from gray to black in both basins occurred at around 1870 when development in the basin intensified. In addition, concurrent with the change in sediment color was a general decrease in sediment organic content in the center of the lake between the 1863 and 1905 horizons (Fig. 7). Meyers et al. (1980) indicated that a period of higher terrestrial inputs to Pyramid Lake occurred at a depth of $20 \mathrm{~cm}$ in sediments from near Anaho Island which the authors attributed to increased erosion due to development. In our cores, the n-alkane $\mathrm{C}_{29}$ data for the center of the lake also indicates an increase in terrestrial inputs between 1863 and 1893 (Fig. 8). Thus, our data supports the previous interpretation of Meyers et al. of increased erosion in the Truckee Basin in the late 1800's due to development. However, an alternative explanation is that the late 1800 's was a period of generally high precipitation in the Sierra Nevada mountains (e.g. Fig. 6) suggesting that part of the increased sediment loading may be due to climatic variations affecting river inflow to the lake (see below). It is noteworthy that the organic content of sediments in the shallow basin increased dramatically sometime during the 19th Century, and it is possible that the increase may be associated with the tremendous amount of milling debris deposited in the river throughout 1870-1900 (Townley, 1980).

It is noteworthy that the organic content of sediments in the deep basin actually decreased after the period of high productivity in the early to middle 1900 's. For all organic fractions, values decreased around 1960 to ones similar to those recorded for 1900 . This suggests decreasing productivity in the lake during 1945-1960. Further, the elemental composition of organic matter in the 1960 horizon was less characteristic of phytoplankton biomass than during 18931945, with increases in the C:N, C:P, and N:P ratios of organic matter. Thus, historical changes in the organic content of sediments from the deep basin of Pyramid Lake deviate from the typical pattern observed in many lakes affected by cultural eutrophication where nutrient and organic matter content are highest in surface sediments (Goldman \& Horne, 1983). This suggests that other factors in addition to nutrient loading affect the historical levels of productivity recorded in the sediments of Pyramid Lake. 


\section{Influence of climate}

Variations in the composition of sediments in the shallow basin indicate that fluctuations in lake level may play a large role in determining the $\mathrm{CaCO}_{3}$ and organic matter content of sediments. With the exception of the upper two centimeters, $\mathrm{CaCO}_{3}$ and organic content of shallow basin sediments have generally decreased since the 1909 horizon (Figs. 4 and 7). These changes in sediment composition occurred concurrent with the large reduction in total inflow to the lake due to agricultural diversion and a large decrease in overall lake depth (Fig. 2). It is interesting that the water content of sediments in the shallow basin also decreased during the 1900's (Fig. 4), indicating a potential increase in average particle size (e.g. Berner, 1980) as lake level decreased. One possible explanation for these observed patterns is that the focusing of small presumably organic rich particles from the shallow basin to the center of the lake becomes more efficient as the depth in the shallow basin decreases. A potential mechanism contributing to greater focusing of fine particles from the shallow basin to the center of the lake with decreasing water depth is an increase in the importance of resuspension processes at shallower depths.

Concurrent with the dramatic decrease in lake level during the 1900 's is an increase in sedimentary inorganic $P$ in both basins. It is interesting that a minimum for inorganic $P$ occurred around 1880 when the lake was at its highest level in recorded history (CDWR, 1991). Figure 10 compares the sedimentary inorganic $\mathrm{P}$ in the deep basin with the approximate lake volume at the time of deposition. Clearly, an inverse relationship is apparent between sedimentary inorganic $\mathrm{P}$ in the deep basin and lake volume at the time of deposition. We suspect that this inverse relationship between inorganic $\mathrm{P}$ and lake volume is due to geochemical particle interactions which may contribute to the regulation of phosphate concentration in Pyramid Lake (see Lebo et al., 1994). From a practical standpoint, we can use this inverse relationship to estimate variations in lake level in the past. Examining historical changes in sedimentary inorganic $\mathbf{P}$ in the deep basin (Fig. 4) suggests that water diversions during the 20th Century have caused lake volume to decrease to its lowest levels in the past 600 years.

Variations in the sediment composition of Pyramid Lake concurrent with periods of either high or low river inflow suggests that climatic fluctuations may play a dominant role in determining sediment composition. In several sections of the paper, we have noted cases

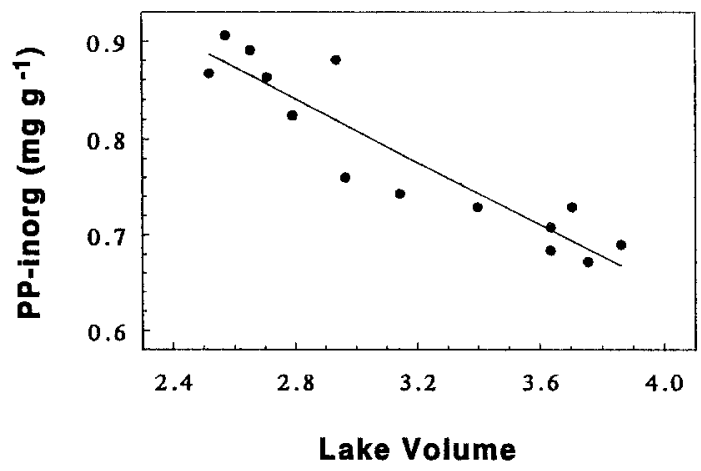

Fig. 10. Plot of sedimentary inorganic $\mathrm{P}\left(\mathrm{PP}_{\text {inorg }}\right)$ in the deep basin (1840-present) versus lake volume $\left(10^{10} \mathrm{~m}^{3}\right)$. Relationship is highly significant $(\mathrm{P}<0.001 ; n=14 ; r=-0.93)$.

where probable variations in river inflow offered alternative explanations to observed patterns. These include increased organic content during the 1600 's, high terrestrial input during the late 1800's, and decreased $\mathrm{CaCO}_{3}$ and organic content during the 1900's. For these examples, observed variations in the sediment composition of one or both of the basins of Pyramid Lake could be explained by a change in the hydrologic balance of the lake. This does not diminish the usefulness of sediment content and biomarkers in evaluating historical patterns of lake productivity. However, it does constrain the simple interpretation of productivity indicators in lake systems, such as Pyramid, that are subject to large fluctuations in lake level and river inflow among years. Changes need to be evaluated both in terms of biomarkers and fluctuations in the hydrology of the system.

\section{Summary and conclusions}

Variations in the composition of Pyramid Lake sediments over the past 1000 years indicate several periods for which productivity may have increased. Our data provide strong evidence for increased productivity during the early to middle 1900 's, although variations in sediment composition do not follow the typical pattern observed for cultural eutrophication. Variations in sediment composition also suggest periods of potential increased productivity in the lake prior to settlement of the region. Indeed, the broad peak in organic fractions during the 1800's began to increase around 1600. However, variations in Truckee River sediment loading probably affect the organic matter content of sediment in Pyramid Lake, confusing the simple inter- 
pretation of changes in sediment organic content over time. The large variations in the organic content of sediment in the center of the lake deposited prior to 1900 also correspond to periods when inflow to the lake was probably at extremes (e.g. drought or flood). This suggests that fluctuations in river inflow may actually be a very important factor affecting sediment composition in Pyramid Lake. It is noteworthy that variations in sedimentary $\mathrm{CaCO}_{3}$ and $\mathrm{P}$ occurred concurrent with these extreme periods providing additional support for the importance of the water balance of Pyramid Lake in determining sediment composition.

\section{Acknowledgments}

Support for this research was provided by the U.S. Environmental Protection Agency under Sections 305 and 106 of the Clean Water Act. We thank Wendell Smith of U.S. EPA Region IX and Jim Cooper of Nevada DEP for their continued support. Acknowledgment is also made to the donors of the Petroleum Research Fund, administered by the American Chemical Society, for partial support of this research. A special thanks go to Paul Wagner, Dan Mosely, Nancy Vucinich, and Beverly Harry for aid in sampling and Cathy Rhodes and Jeanete Povoa for sample analyses. We thank Gabrielle Tenzer for the organic matter analyses, Rich Jepson for particle size distribution analyses, and David Edgington for ${ }^{210} \mathrm{~Pb}$ analyses. Larry Benson provided valuable background information, discussions on Pyramid Lake sediments, and helpful comments on an earlier draft of the manuscript. Work was done in cooperation with Pyramid Lake Fisheries representing the Pyramid Lake Paiute Indian Tribe.

\section{References}

Aspila, K. I., H. Agemian \& A. S. Y. Chau, 1976. A semi-automated method for the determination of inorganic, organic and total phosphate in sediments. Analyst 101: 187-197.

Benson, L. V., 1984. Hydrochemical data for the Truckee River drainage system, California and Nevada. U.S. Geological Survey Report 84-440, Denver, Colorado, 35 pp.

Bemer, R. A., 1980. Early Diagenesis. A Theoretical Approach. Princeton University Press, Princeton, N.J., $241 \mathrm{pp.}$

Broecker, W. S. \& T.-H. Peng, 1982. Tracers in the sea. Elidigio Press, Palisades, N. Y., $690 \mathrm{pp}$.

California Department of Water Resources (CDWR), 1991. Truckee River Atlas. California Department of Water Resources, 128 pp.

Carignan, R. \& D. R. S. Lean, 1991. Regeneration of dissolved substances in a seasonally anoxic lake: The relative importance of processes occurring in the water column and in the sediments. Limnol. Oceanogr. 36: 683-707.

Cranwell, P. A., 1977. Organic geochemistry of Cam Loch (Sutherland) sediments. Chem. Geol. 20: 205-221.

Crusius, J. \& R. F. Anderson, 1991. Core compression and surficial sediment loss of lake sediments of high porosity caused by gravity coring. Limnol. Oceanogr. 36: 1021-1031.

Eadie, B. J., R. L. Chambers, W. S. Gardner \& G. L. Bell, 1984. Sediment trap studies in Lake Michigan: Resuspension and chemical fluxes in the southern basin. J. Great Lakes Res. 10: 307-321.

Edgington, D. N., J. V. Klump, J. A. Robbins, Y. S. Kusner, V. D. Pampura \& I. V. Sandimorov, 1991. Sedimentation rates, residence times and radionuclide inventories in Lake Baikal from ${ }^{137} \mathrm{Cs}$ and ${ }^{210} \mathrm{~Pb}$ in sediment cores. Nature 350: 601-604.

Edmondson, W. T., 1991. Sedimentary record of changes in the condition of Lake Washington. Limnol, Oceanogr. 36: 10311044 .

Engleman, E. E., L. L. Jackson \& D. R. Norton, 1985. Determination of carbonate carbonin geological materials by the coulometric titration. Chem. Geol. 53: 125-128.

Engstrom, D. R., 1983. Chemical stratigraphy of lake sediments as a record of environmental change. Ph. D. dissertation, Univ. of Minnesota.

Engstrom, D. R. \& H. E. Wright, Jr., 1984. Chemical stratigraphy of lake sediments as a record of environmental change. In E. Y. Haworth \& J. W. G. Lund (eds.), Lake sediments and environmental history. Leicester University Press: 11-67.

Galat, D. L, \& R. L. Jacobsen, 1985. Recurrent aragonite precipitation in saline-alkaline Pyramid Lake, Nevada. Arch. Hydrobiol. 105: 137-159.

Galat, D. L., E. L. Lider, S. Vigg \& S. R. Robinson, 1981. Limnology of a large, deep, North American terminal lake, Pyramid Lake, Nevada, USA. Hydrobiologia 82: 281-317.

Goldman, C. R. \& A. J. Horne, 1983. Limnology. McGraw Hill, New York, $464 \mathrm{pp}$.

Hutchinson, G. E., 1937. A contribution to the limnology of arid regions. Trans. Conn. Acad. Arts Sci. 33: 47-132.

Jones, M. N., 1984. Nitrate reduction by shaking with cadmium: an alternative to cadmium columns. Wat. Res. 18: 643-646.

Kemp, A. L. W., R. L. Thomas, C. I. Dell \& J.-M. Jaquet, 1976. Cultural impact on the geochemistry of sediments in Lake Erie. J. Fish. Res. Bd Can. 33: 440-462.

Kendall, R. L., 1969. An ecological history of the Lake Victoria basin. Ecol. Monogr. 39: 121-176.

Klapwijk, S. P. \& C. Bruning, 1986. Available phosphorus in the sediments of eight lakes in the Netherlands. In P. G. Sly (ed.), Sediments and water interactions. Springer-Verlag, N.Y.: $391-$ 398.

Lebo, M. E. \& J. E. Reuter, in press. Spatial variability in sediment composition and evidence for resuspension in a large, deep lake. Aust. J. mar. Freshwat. Res.

Lebo, M. E., I. E. Reuter \& C. R. Goldman, 1994. Natural phosphorus control in a terminal lake: implications for lake management. Lake Reserv. Mgmt. 9: (in press).

Lebo, M. E., J. E. Reuter, C. L. Rhodes \& C. R. Goldman, 1992. Nutrient cycling and productivity in a desert saline lake: observations from a dry, low-productivity year. Hydrobiologia 246: 213-229.

Leenheer, M. J., K. D. Flessland \& P. A. Meyers, 1984. Comparison of lipid character of sediments from Great Lakes and the Northwestern Atlantic. Org. Geochem. 7: 141-150.

Lerman, A., 1979. Geochemical processes. Water and sediment environments. Wiley \& Sons, N.Y., 481 pp. 
Liddicoat, M. I., S. Tibbitts \& E. I. Butler, 1975. The determination of ammonia in seawater. Limnol. Oceanogr. 20: 131-132.

Meyers, P. A., 1994. Preservation of elemental and isotopic source identification of sedimentary organic matter. Chem. Geol. 114: 289-302.

Meyers, P. A. \& R. Ishiwatari, 1993. Lacustrine organic geochemistry - An overview of indicators of organic matter sources and diagenesis in lake sediments. Org. Geochem. 20: 867-900.

Meyers, P. A., O. E. Kawka \& D. R. Whitehead, 1984. Geolipid, pollen and diatom stratigraphy in postglacial lacustrine sediments. Org. Geochem. 6: 727-732.

Meyers, P. A., H. B. Maring \& R. A. Bourbonniere, 1980. Alkane and alkanoic acid variations with depth in modern sediments of Pyramid Lake. Proceedings of Ninth International Meeting on Organic Geochemistry.

Milne, W., 1987. A comparison of reconstructed lake-level records since the mid-1800's of some Great Basin Lakes, M.S. Thesis, Colorado School of Mines, Golden, $207 \mathrm{pp}$.

Ostrofsky, M. L., 1987. Phosphorus species in the surficial sediments of eastern North America. Can. J. Fish. aquat. Sci. 44: 960-966.

Reuter, J. E., C. L. Rhodes, M. E. Lebo, M. Kotzman \& C. R. Goldman, 1993. Nitrogen limitation in a saline, desert lake. Hydrobiologia 267: 179-189.

Robbins, J. A. \& D. N. Edgington, 1975. Determination of recent sedimentation rates in Lake Michigan using Pb-210 and Cs-137. Geochim. Cosmochim. Acta 39: 285-304.

Sasseville, D. R. \& S. A. Norton, 1975. Present and historical geochemical relationships in four Maine lakes. Limnol. Oceanogr. 20: 699-714.
Solorzano, L., 1969. Determination of ammonia in natural waters by the phenolhypochlorite method. Limnol. Oceanogr. 14: 799-801.

Solorzano, L. \& J. H. Sharp, 1980. Determination of total dissolved phosphorus and particulate phosphorus in natural waters. Limnol. Oceanogr. 25: 754-758.

Strickland, J. D. H. \& T. R. Parsons, 1972. A practical handbook of seawater analysis, 2nd ed. Fish. Res. Bd Can.

Stumm, W. \& J. J. Morgan, 1981. Aquatic Chemistry, 2nd ed. Wiley \& Sons, N.Y., $780 \mathrm{pp}$.

Townley, J. M., 1980. The Truckee Basin fishery, 1844-1944. Water Resources Center Publ. 43008, Desert Research Institute, Univ. Nevada, Reno, 88 pp.

Williams, J. D. H., J. K. Syers, S. S. Shukla, R. F. Harris \& D. E. Armstrong, 1971. Levels of inorganic and total phosphorus in lake sediments as related to other sediment parameters. Envir. Sci. Technol. 5: 1113-1120.

Williams, J. D. H., T. P. Murphy \& T. Mayer, 1976. Rates of accumulation of phosphorus forms in Lake Erie. J. Fish. Res. Bd Can. 33: 413-429.

Wünsche, L., Y. A. Mendoza \& F. O. Gulacar, 1988. Lipid geochemistry of a post-glacial lacustrine sediment. Org. Geochem. 13: 1131-1143.

Zasoski, R. J. \& R. G. Burau, 1977. A rapid nitric-perchloric acid digestion method for multi-element tissue analysis. Comm. in Soil Science and Plant Analysis 8: 425-436. 